\title{
Influence of Chinese and Western cultural differences on English learning
}

\author{
Zhao Hui Min ${ }^{1, \text { a }}$ \\ ${ }^{1}$ Bohai university, Jinzhou, 121013 China \\ ahmzhao2008@163.com
}

\begin{abstract}
Keywords: Chinese and Western culture; cultural differences; English learning; factor analysis; comparative analysis.
\end{abstract}

\begin{abstract}
In recent years, English learning has become civil learning, and the importance of English learning is widely recognized. Learners of English have long been aware of the influence of cultural factors on English learning and its significance. Culture is the carrier of language. Language is the important tool of communication, which ties people together. Each nation has its own culture, which is expressed in the form of language. We should learn to grasp the cultural factors to better learning English. In this article, we studied cultural differences between Chinese and Western cultural, i.e. the belief, customs, ways of thinking, in order to improve the thinking of English learning and learning ability. Firstly, the relationship of language and culture was elaborated, and then through a large number of examples, the author made a comparative analysis on the differences between Chinese and Western cultures in English words and idioms, so as to clarify the important influence of cultural differences on English vocabulary learning.
\end{abstract}

\section{Introduction}

With the expansion of the development of linguistics and intercultural communication, people have come to realize that language is not a system of signs, that is the sum of pronunciation, grammar and vocabulary, but a kind of social phenomenon, is closely connected with culture. Therefore, language learning is impossible to avoid cultural problems; to communicate better, too we must know more about the cultural differences between different languages. For us, is to understand the differences between Chinese culture and Western culture, to really master English, can be used accurately and appropriately communicate. The general culture refers to the sum of material and spiritual wealth created by human in the process of social and historical development. It includes three aspects: material culture, system culture and psychological culture. Material culture refers to all kinds of material civilization created by mankind; it is a visible dominant culture, such as production and transportation, clothing, household appliances, etc. System culture and psychological culture are invisible hidden culture. The former refers to all sorts of system and theoretical system, such as system, family system, social system and the related system of these various theories system; the latter refers to the way of thinking, religious beliefs [1], aesthetic values, etc. The narrow sense of culture refers to people's social customs and habits, life style, mutual relations and so on. Culture is a kind of social phenomenon, which is the product of people through their creative activities. Culture at the same time is a kind of historical phenomenon, is the accumulation of social history. Each generation inherits its original culture, and at the same time, it also makes a contribution to the development of social culture. Culture has a distinctive national character, and it is the symbol of national differences. Because of the different regions, ecological environment, social political and economic system, historical background, customs and habits, values, behavior patterns and so on, its culture also has its own characteristics. 


\section{The important influence of culture and its function}

\section{The influence of cultural differences on English Vocabulary Learning.}

Language and culture are inseparable. Language is not only a symbol system, but also to people's verbal forms of language for the existence of social / community (community) of the customs, life style, behavior, values, ways of thinking, religious belief, restriction and influence of national mentality and personality etc.. For a long time, the relationship between language and culture has not been paid enough attention in English teaching. In teaching practice, many teachers seem to think that as long as the listening, reading, writing training, master the pronunciation, vocabulary and grammar rules will be able to understand English and communicate in English. But in fact due to lack of understanding of the cultural background of the language, do not understand the differences between Chinese and Western culture, in English learning and communication in English often appear ambiguity frequent misunderstandings, phenomenon of pragmatic failures one after another. Such as: How much money can you earn a month? For the foreigners concerned, not knowing that this is an offensive question, violated the privacy of others, will provoke other people. Chinese for virtue to humility, such as when foreigners praise a hand Chinese expertise, Chinese usually use "You are over praising me (" the lottery) to socialize, which often make the speaker feel you doubt his judgment; or "Where? Where? (where, where)" answer, make foreigners rather baffling, unintelligible. The American sociologist G.R.Tucker and W.E.Lambet for foreign language teaching in the language not only taught to have such a view: "we believe that the culture of any such attempt will make students lose interest, so that they not only do not want to learn the language itself, but also don't want to use this symbol system of the nation. Instead, to help students improve their sensitivity to culture in the learning of language, they can use their heart to understand the interests and motivation of other peoples, thus providing the basis for learning the language of the nation [2].

\section{Difference between Chinese and Western Education.}

Chinese ancient modern education and Confucianism has held a dominant position in the history of western education, education is the western performance colorful emerge in an endless stream, the historical features of Athens's "liberal education" heavy weight harmonious physical and mental development, Sparta heavy physical training, heavy patriotism, both diversity, Western education. Western education has many schools of thought in the development of the Chinese nation, the value orientation of backward thinking, "one" and "many" complementary, so in the field of education will focus on the history of the mainstream and the classical knowledge inheritance, and the value orientation of western attention from reality to the future movement, in the way of thinking "and" "many" the unity of opposites of tradition, especially encourage exploration, so education must emphasize the creation of. The concept of western education in the education form out of focus on the differences from the similarities and differences. China teaching is basically a continuation of the theory of knowledge, closed. Lack of breakthrough changes to block the production of new concepts of education, the opening of the west, not only can inherit reasonable, and even doubt, continue to introduce new. The United States University of the credit system, students can choose according to personal preferences of different subjects, different subjects of credit, as long as the full credits, get a diploma and degree, University of the United States Constitution is very flexible, students can choose several different professional courses, as long as get enough credits to get professional degree in the University of China. In the professional course, a person may be a lifetime in a professional, may ignore a person's potential.

\section{Differences between Chinese and Western Environment.}

Chinese culture in the diet, family education environment is very unique. Chinese diet culture is embodied China cultural tradition, pay attention to the production of every rhythm, edible flavor and taste, while the west is more focused on nutrition, collocation is free. China focus on "harmony" Westerners focus on "people-oriented" the value of the difference between the concept of form, consciousness of Chinese ideographic, to send material. Western cuisine is a kind of labor, and in the 
Chinese when cooking a kind of art, Chinese love unity with round and square table with reflected, Westerners use knives and forks to give a murderous, Chinese treat the "shared" stressed "confluence". Western dinner popular dining system, the performance of respect for the individual. Family education is very different from the western families as the center, the Chinese family with father and son as the center of the family, China used to be popular in the family, the western popular family system. The so-called family China historical and cultural values, basically is the family values, the idea of the value orientation of the traditional concept of family characteristics, many family rules, the ancient Chinese family and home ring shall not violate China requirements, family values and safeguard the interests of the family, personal interests in a subordinate position, not even individual interests. The detention of the personal development. Western popular explanation, the family is lasting between husband and wife with children for family organization, the daily economic life, a child to adulthood, they will leave the nest and fly, the parents do not raise their children, with independent, don't ask for parents with housework[3].

\section{Differences of ethnic customs and English learning}

\section{Summary of ethnic customs.}

The national customs mainly refers to the people in daily life, in the process of human communication from the national customs and habits of the formation of culture. People living in what kind of environment, will produce what kind of language. For example: Salad this salad originated from France, the British first have this dish, language does not exist in the word, so from the French intact "transplantation". So is the Chinese language. In our country, the problem of eating has long been a special concern of people, which has become a topic of conversation. People always love to say: "have you eaten?" In general, the speaker is not very concerned about the listener is not eating a meal, just say hello. But if you ask the Englishman, "have you eaten?" His first reaction was "how, didn't you eat me?"'" Sometimes may resent people to question, "why not eat, I eat a meeting and asked not to eat, and none of your business?" Because of the cultural differences, the expression and many around the "eat" problems set up by the word in Chinese, but in English it is difficult to find the corresponding expression method, for example, we say "idlers" (1ead all idle life), "popular" (be very popular), "too much" more than one can stand. Too much and so on), English cannot correspond to words. When others compliment, the Chinese are always very modest, saying "where, where, where"!" "No, no, no!" This will make the Westerners feel puzzled, so that their embarrassment. In addition, the Chinese people to marry his wife, he called the birthday of "red Hi"; the old man died called white xi". For the United States has no contact with the culture of the United States and Europe, the wife said to be "red Hi" is not difficult to understand, the day of the festival called letter - day red". But the death of old people as a "happy event", which makes them strange. Therefore, compared with the European and American culture, the dead is called "white Xi" is the personality of our culture.

\section{Differences in religious beliefs and English learning.}

Westerners believe in Christianity, that the world was created by God, all the world's arrangements are also in the will of God, and Christianity in western history once dominated, the power of the church is often superior to the monarch. In China, only "the creation of the world" and the "master of Pangu nature God in people's mind". God and God are represented by something very different, meaning is not the same. Especially the concept of "God", which has a strong Christian color, is the character of European and American culture. God in Buddhism should not be mixed with Christianity in the "God"; "Heaven" is a Buddhist followers believe. For example, both Chinese and English are "long" words, the corresponding words in the English language is "dragon"'. In ancient China, "a symbol of the dragon" is the emperor, the emperor regarded themselves as "dragon", and the emperor's sons are called "dragon dragon sun". And the imperial residence, wearing with "dragon" crown, robe, dragon bed: long Ting, Longyan; later extended to rare, noble and auspicious symbol, "dragon" Chinese commonly linked to themselves or others, such as our yellow skin, black eyes were Yan Huang Zisun known as the "dragon", parents hope that their next generation of growth for the 
country useful, this people often say "Wangzichenglong"; "phoenix" said prosperity, prosperity. As can be seen from the above example, the Chinese people on the "dragon" is much respected; but in the western countries, such as the United Kingdom, "dragon" the meaning of the cultural connotation of "monster, cruel, the devil" and so on. Western culture in different religious beliefs in their language, the difference is only a profound understanding of the cultural personality of East and West, understanding the cultural meaning of language in order to make learning English really play the role of cultural exchange[4].

\section{Geographical differences and English learning.}

In western countries, the geographical and natural conditions and geographical environment is different, the same phenomenon or things form of the language is different, for example, the geographic differences in the range and its counterpart, it reflected more prominent. In Chinese, since ancient times there is king, North Korean and south and North are humble respect for tradition, when speaking in front and in the north is the south, such as "always on the move, from the south to the north"; while the English culture is just the opposite, British and American English from the regional culture to understand Chinese from the south to the north, north to south is from; northwest, southwest, northeast and southeast direction words, English and Chinese, respectively North - West, SOUtl1west, northeast, SOUtl1east etc.. In the Chinese mind, a symbol of spring, the warm wind of Italy, the custom of Dongfeng Primal; while the British wind is from the north of the continent blowing, a symbol of the cold, unpleasant, so the British people hate Dongfeng, but love wind, because it gave the British sent to the spring, so it is called "west wind Primal" said. By the Chinese readers of the British Romantic poet Shelley has a song of "Ode to the west wind" (Ode to the West Wind) is the westerly praise. One of the " 0 wind, Winter comes if, Spring is far behind call?" (9 A, the west wind, winter has arrived, will spring be far away?) I do not know how many people in need of incentive to make progress, so that they are full of yearning for a better and confidence for the future. Different geographical areas, so that people will have different views on the same thing and understanding. Some things in a culture are considered a symbol of good, but in other cultures is seen as no sense of ordinary things.

\section{Differences between national Proverbs.}

Chinese dominated by agriculture, heavy snow of winter crop benefits, snow bigger next year's crop is better, so there is a "mega Ruixue year" said. In China the traditional culture, is the symbol of diligence, dedication of cattle, so people love to those hard working people compared to the old cattle. Chinese love cattle, because cattle farming and farmers, and stay together morning and night are an integral part, become wealthy farmer's life. The horse for livestock farming on the understanding of the country may be quite different. So, the British people do not speak what "laohuangniu spirit", but to say "work like a horse", "work like dog" (hard work, hard work and so on).

\section{Historical allusion differences and English learning}

\section{An overview of cultural and historical differences.}

Different nationalities, using different languages, have different histories, different cultural traditions and different customs of life. Historical allusion is a treasure in the history and culture of the nation; it has strong national characteristic and distinct cultural individuality, and contains rich historical information. For example, in Chinese, "Pan Gu created heaven and earth", which "Pangu" characters China legend, the name has the meaning of the one and only is an illusion. Only exists in the language culture of china. The same as the source of western culture, "the Bible" is also unique to western, and the "Bible" in figure Cain has extended "fratricidal fighting", accepted by the people of the world, all of which has become Europe's cultural heritage. On Chinese, these are cultural personality, culture and China incompatible. In western culture, much historical allusion comes from ancient Greece and Rome myth and the Bible story. Please look at the example: You are doubting Thomas just a doubtingThomas.You won t source believes what I tell you. in this sentence in the Bible, Thomas is 
one of the 12 disciples of Jesus, the life of paranoia. Later, in English doubtingThomsa, suspicious person. Understanding of the cultural connotation, we can be understood as: you're paranoid; I do not believe what you say. The characters and events in the works of famous writers (such as Shakespeare, etc.) are often literary quotations. For example: Many took to gambling and got in over their heads, borrowing from Shylocks to pay their debts. the Shylock is not Shakespeare's "the merchant of Venice" that the "Sherlock", but as a story, pass those who care about usury. If you do not understand the original story cannot be very accurate understanding of its meaning [5].

\section{Summary}

With the international cultural exchanges continue to expand, gradually narrowing the gap of human culture, language as an important carrier of culture also affected the same emphasis on cultural knowledge and learning, can not only bring fresh elements into the local culture, but also can promote the spread of the national culture to the outside, to achieve the purpose of cross culture communication, to accelerate the process of "cultural globalization". In terms of the true success of language learning, the learner's double culture is even more important than the two language skills, because the word is only meaningful in the context of its cultural context. The influence of cultural differences on language learning cannot be underestimated. To strengthen the study of language and cultural differences is a subject that must be studied and discussed in the process of English learning.

\section{Acknowledgements}

The province social science fund :L15DWW005.

\section{References}

[1] Wu Ye. Advertising language reflects the cultural differences between Chinese and Western literature education research [J]. (below). 2016 (05).

[2] song Ke. A discussion on the differences between Chinese and Western cultures and the translation of [J]. overseas English. 2011 (02).

[3] Wu Xiaoling. Example analysis of Chinese and Western cultural differences on the impact of daily communication [J]. Chinese school education. 2012 (36).

[4] Wang Feifei. The differences between Chinese and Western culture influence on English Chinese translation [J]. Journal of Tai'an Institute of education. Journal of mountain 2010 (02).

[5] Gao Lei, Hu Bo, Wang Zhichen. Chinese and Western cultural differences and College English Listening Teaching [J]. Journal of Mudanjiang Medical University. 2010 (04). 